\title{
Transformation in Russian adult additional education
}

\author{
Valentina Abraukhova*, and Anastasija Zimovetc \\ Don State Technical University, 344000, Rostov-on-Don, Russia
}

\begin{abstract}
The present work considers the development of adult education in Russia from the elimination of illiteracy from the late 19th - early 20th centuries to the use of information and communication technologies at the beginning of the 21 st century. The aim of the article is to consider the stages of development of adult education and to determine at the stages of development the most sought-after educational areas and technologies in additional adult education. In this work, differences in the process of teaching children and adults are considered, an excursion is made into the history of the formation of adult education in Russia. A modern picture of additional adult education is given. Based on the studies, the authors conclude that for adults the most sought-after educational field is the study of a foreign language using remote technologies.
\end{abstract}

\section{Introduction}

Adult education was the object of interest such great scientists as Socrates, Plato, J.A. Komensky, F.A.V. Diesterweg and many others. A lot of outstanding teachers of ancient times taught adults, not children. Such teachers include Confucius, Aristotle, Socrates, Euclid, and others. Already at that time there were methods of teaching adults, for example, Socratic dialogue, invented in ancient Greece. The methods of the ancient Romans were more warlike - the most famous is the test method, which forced students to establish positions and protect them. Adult education appeared much earlier than the education of children. However, it was not in demand for a long period of time, which is associated with the socio-economic conditions of being. People acquired skills and subskills during childhood education, and these skills and subskills were enough for the rest of their lives. In the formation of adult education, Russia began its journey with the campaign against illiteracy. The idea of adult education received the first impetus in the Russian Empire at that very time. It was in the middle of the 19th century when the first Sunday schools opened their doors for the majority of people. They grew up with the help of such personalities as N.A. Korf, N.I. Pirogov, K.D. Ushinsky, V.I. Vodozov, V.Ya. Stoyunin. The main idea of Sunday schools was the idea of public education for adults. It was K.D. Ushinsky who first put forward the idea that adult education should be directly related to their work activities: "real, practically important educational goals, its developing and continuous nature, the connection of training with production activities, the use of the life experience of students, visibility, and individualization" [1]. Among other things, the

\footnotetext{
*Corresponding author: childrenpalace@ mail.ru
} 
Government of the Russian Empire raised the question of increasing the number of teachers and teachers of higher education, since the result of the abolition of serfdom was a systematic increase in students - up to about four to five million in the country. V.P. Vakhterov in 1917 became the first teacher to develop the theory of extracurricular education, it is shown in his work "National School and Extracurricular Education". In 1897, according to the results of the first population census in Russia, $78.9 \%$ of people were illiterate. The field of education faced complicated tasks. In 1906, the first public university was opened in Moscow; public universities were opened all over the country. There were already 16 of them and by the end of the first decade of the 20th century. It should also be mentioned that after October 1917, it was a very difficult time for education in the country, as the process of destruction of the education system began. The previous structures of school administration, private institutions were abolished, and a prohibition on teaching in any educational institutions of ancient languages and religions became valid. A drop-out of untrustworthy teachers was also carried out. In December 1917 - March 1918 there was a mass strike of teachers, which was declared illegal. Many teachers refused to obey the Soviet government, accusing it of violating the foundations of democracy and terror. Despite the dissatisfaction of teachers, it should be mentioned that the status of a public teacher was raised to a height with the advent of Soviet power. Teacher E.N. Medynsky in 1918 actively uses the term "andragogy." E.N. Medynsky defines extracurricular education as "the comprehensive development of the personality in mental, moral, aesthetic and physical terms" [3]. N.K. Krupskaya was active in promoting the principle of connecting education with life, practice and industrial work. She formulated the requirement of universal polytechnic education and the need to create adult schools for the illiterate and illiterate. At the so-called working faculties, students were engaged not only in general education, but also in production. In the 1950-1960s, adult extracurricular education was considered, first of all, as a system of party - political education. By the $80 \mathrm{~s}$ of the XX century, a contradiction arose between the increased scope of higher education and the economic lag of the state, so in 1987 a restructuring was announced in higher school, which was aimed at integrating education, production and science. It was planned to improve the educational process and change educational work in higher educational institutions.

\section{Materials and Methods}

In the 90s of the XX century, the educational system in Russia was extremely changed. A course on democratization was taken, private educational institutions were introduced, and pedagogical relations between the teacher, students and parents reached a new level - the level of cooperation. The Federal Law "On Education in the Russian Federation" (2012) stoned the status of adult education, which main goal was the formation and development of creative abilities of children and adults, meeting their individual needs for intellectual, moral and physical improvement, the formation of a culture of a healthy and safe lifestyle [4]. Increasing competence is an incentive to improve the quality of one's own knowledge, as well as to improve one's own competitiveness in the labor market. Thus, factors such as the development of scientific and technological progress, socio-economic life and the desire for self-improvement are the motivation for lifelong learning and contribute to an increase in the number of people wishing to study in adulthood, throughout life. As a fact, scientists understood that changing the age group when learning something requires reworking existing methods, theories and concepts. The andragological model formed the basis for the creation of methods in the education of adult students, where the main principles are awareness of increasing self-management; life experience [5]. Based on all above, it can be concluded that the education of adult learners should have an and ragological model of 
learning in order to achieve the best results. The authors investigated trends in the development of additional adult education [6], the use of technologies in modern digital space $[6,7]$. Today we present new research in the area under consideration. The most popular educational field of adults is the study of foreign languages. The All-Russian Center for the Study of Public Opinion (VTSIOM) presented the data of the 2019 study. According to the majority of respondents (63\%), learning a foreign language is necessary in modern conditions, with $93 \%$ of them preferring learning English. There 78 adults participants (age between 25 and 65 years old) and 78 children (age between 6 and 15 years old) took part in the survey.

\section{Results}

We conducted a study in which 30 teachers took part, teaching adults a foreign language remotely. Based on the survey, we identified the features of working with an adult audience. Teachers, rely on life experience. Adults are more conservative, with difficulty entering into dynamic creative activity. It is very important for them to do the right thing, they are afraid to be mistaken and not look attractive in the eyes of the teacher, although the teacher more often younger than the student is. This was also tested in foreign language lessons during the year on the basis of an English language course at the Palace of Creativity of Children and Youth of Rostov-on-Don. The use of various kinds of techniques in accompanying adults to personally enrich knowledge and help their children and grandchildren. It is the participation of adults in the process of mutual learning with the younger generation that gives a sense of security and removes a number of psychological clamps in the process of learning. Starting the program of immersion and mutual training, the main one was the system of diagnostic targeting:

1) Definition of objectives (for what?)

2) Selection and structure (what?)

3) Methods and techniques (with what?)

4) Teacher qualification (who?)

5) Outcome assessment methods (how?)

Various job options are offered for:

- strengthening of language material and development of language skills;

- formation of various types of speech activities;

- -development of sociocultural and communicative competence

Tasks on the methodology of interval and intensive repetitions along the direction from simple to complex were most often used by us at the initial stage of the experiment, but this experience is easily implemented at any level of teaching and language proficiency or is part of more complex tasks along the chain. Starting with the phonetic dictation, we use the screen-o-matic program as an electronic resource, for recording and training phonological hearing. In this task there are moments of self-training and ICT training. With the help of adults, children learn a new technology. This process does not end at the stage of completing the task, all tasks are saved by the teacher on the Padlet electronic board, and are posted remotely by the parent or student. The board itself is a generalized form of lesson history with completed tasks and comments on both sides of the training process. This form is very attractive in the mutual training of adults and children. Children are always happy to learn new bright technologies, and adults keep the learning process in a constructive way, thereby learning language and technology. In an interactive board, you can embed more than just tasks on phonetics. The interactive capabilities of this resource help to discuss remotely various topics of the lesson, which is an already more complex geolocation task using Google maps. The proposed route in the form of a reference is attached to the board and comments are given to it on the passage of the route and the final 
task in the form of a written task attached to the board. In the process, sociocultural competence and written speech develop. Perhaps, in conclusion, I would like to mention such tasks as a quest or a project. Their use is the most labor-intensive for the teacher, but also the most successful in terms of team training. We give the task in stages, having previously described the strategy and rules of the project or quest. These tasks have comprehensive support in terms of electronic resources, starting with the LMS (learning management system) Google classroom, Moodle. Interactive boards and shell programs are added to them. The trajectory of learning using RBM is also being built (Oxford, Cambridge, Mirriam-Webster electronic dictionaries, you tube training channels). Everything is in a roadmap of rules and intermediate tasks, tests. The result is a project provided in the form of a study on the topic and presented to an audience of listeners. Interim meetings are in zoom, where participants can be divided into groups for discussion using special session rooms and return with a response. In this kind of mixed-type tasks, adults show great interest due to the discipline of the student, the lack of embarrassment in front of the group or audience, as well as the multitasking of the learning process "I am my child, my grandson," a separate item is the increased academic performance of such couples, increasing the authority of adult rapprochement within the family [8,9].

Table 1. The start of usage online resources

\begin{tabular}{|c|c|c|}
\hline start of usage & & \\
\hline & children & adults \\
\hline zoom & 78 & 78 \\
\hline padlet & 45 & 78 \\
\hline google classroom & 47 & 78 \\
\hline quizlet & 78 & 78 \\
\hline kahoot & 78 & 72 \\
\hline ed puzzle & 45 & 71 \\
\hline chatter pix & 61 & 78 \\
\hline
\end{tabular}

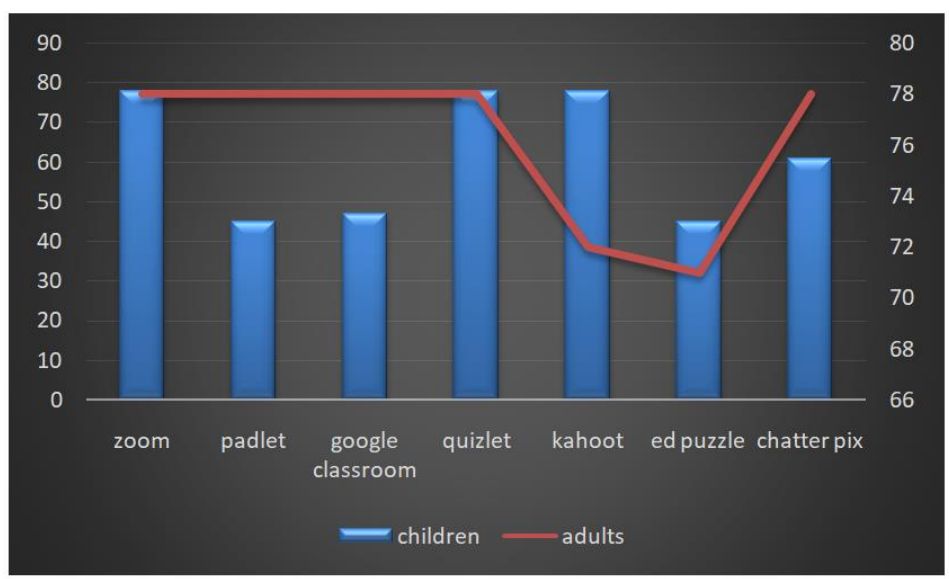

Fig. 1. The start of usage online resources

Table 2. The level of satisfaction of participants

\begin{tabular}{|l|l|l|}
\hline satisfaction level & & \\
\hline & children & adults \\
\hline
\end{tabular}




\begin{tabular}{|c|c|c|}
\hline zoom & 34 & 78 \\
\hline padlet & 25 & 50 \\
\hline google classroom & 25 & 14 \\
\hline quizlet & 61 & 73 \\
\hline kahoot & 30 & 15 \\
\hline ed puzzle & 45 & 71 \\
\hline chatter pix & 61 & 10 \\
\hline
\end{tabular}

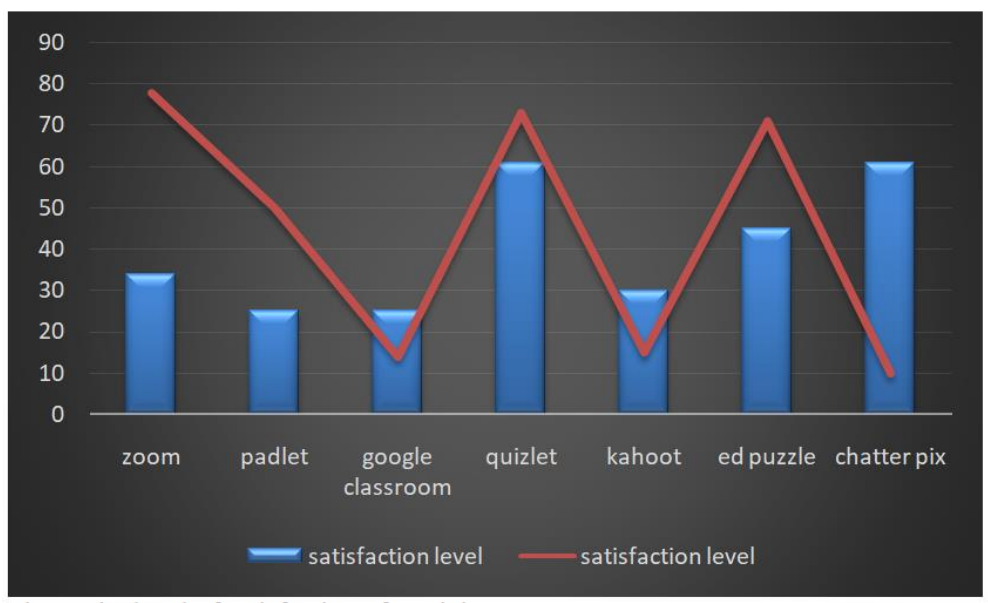

Fig. 2. The level of satisfaction of participants

According to survey numbers the most popular online resources for children are quizlet, chatter pix, the most popular online resources for adults are zoom, quizlet, ed puzzle.

\section{Discussion}

The challenges in future education are mainly related to the relationship between the query (demand) and the resource. Scientists, using foresight technologies (foresight-anticipate), determine the singularity process in the near future, when technological progress will become so rapid and products so complex that they will be inaccessible to understanding. Singularity process [10]. In order to avoid the scenario of inability to understand and process this type of information, as well as for painless entry into the stage of a new technical revolution, we have every opportunity to strengthen and develop the neural connections of structures [11]. Possessing the information that languages have a structure and laws, as well as supporting one of the key principles of CEFR - the pan-European assessment scale for language levels from 2018, as well as the Cambridge scale of life competencies and skills supporting it(in particular in learning English). We especially highlight such competencies as - ability to learn (and self-learning including), critical thinking, ability to work in a team, creativity, social responsibility [12]. Learning English by adults is very different from children. They are more likely to drop out because of fear or language barriers. If adults are engaged independently, then there are risks of improper self-training in the most difficult areas of language mastery, namely reproductive. Unlike the receptive (or those that we perceive and process), reproductive skills have the property of a double bottom, namely incorrect perception-learning-reproduction-fixation without checking and practicing with a specialist or native speaker. In the modern learning environment, interest groups are formed (as adult parents and the older generation were 
previously mentioned to help children), as well as communities of support and mutual learning and knowledge testing that can increasingly be organized as spontaneously using a remote form of communication and technical support tools (interactive boards, cloud storage of information and classes with tasks and social networks) [13].

\section{Conclusions} 15].

Currently, English language education is the most popular area of adult education [14, The following conclusions can be shown from the study.

1. The most effective teachers use the communicative method and intensive methods of teaching foreign languages. It allows forming the skills of students and practically use a living language.

2. Teachers include the most used technologies: gaming technologies (business and roleplaying games), presentations, business trainings, case studies, group discussions, project execution, multimedia applications; using digital resources: Lecture Hall, Open Education, duolingo, Skillbox, Arzamas, Coursera.

3. The application of information and communication technologies is becoming more intensive and displaces the teacher. This is due to the benefits of ICT: the information base is expanding and training methods.

\section{References}

1. K.D.F. Ushinsky, Rus school/Comp., Preface, Comment. (Institute of Russian Civilization, Moscow, 2015).

2. A.S. Prugavin, Requests of the people and duties of the intelligentsia in the field of education and education, 2nd ed., value additional - St. Petersburg: type. I.N. Skorokhodova, (1895).

3. E.H. Medynsky, Methods of extracurricular educational work (Petrograd: ed. auth., 1915).

4. Federal Law "On Education in the Russian Federation" from 29.12.2012 N 273-FZ, ed. From 2020/12/8.

5. T.E. Zmeeva, Almanac of modern science and education, St. Petersburg, $1196-101$ (2011).

6. Mihaela Muresan, Procedia - Social and Behavioral Sciences 116, 21, 4722-4726 (2014/2).

7. Dorthy L. Pennington, International Journal of Intercultural Relations 36 (6), 770-779 (2012).

8. Bodil Gjestvang, Sevald Høye, Berit Arnesveen Bronken, International Journal of Nursing Sciences 8 (1) 71-78 (2020). https://doi.org/10.1016/j.ijnss.2020/11/01

9. John A. Henschke, Procedia - Social and Behavioral Sciences 142, 36-46 (2014). https://doi.org/10.1016/j.sbspro.2014/07/5

10. Alison Reid, Jonathan Cook, Conrad Viedge, Caren Brenda Scheepers, The International Journal of Management Education 18 (1) 100334, (2020). https://doi.org/10.1016/j.ijme.2019.100334

11. Christin Tønseth, Procedia - Social and Behavioral Sciences 174, 3330-3341 (2015/2/12). https://doi.org/10.1016/j.sbspro.2015.01.1001 
12. Alison Anderson Holland, Computers \& Education 128, 214-226 (2019). https://doi.org/10.1016/j.compedu.2018.09.026

13. Céline Cocquyt, Chang Zhu, Anh Nguyet Diep, Maurice De Greef, Tom Vanwing, $\begin{array}{lllll}\text { Computers } \& \quad \text { Education } & 103610 & \text { 142, }\end{array}$ https://doi.org/10.1016/j.compedu.2019.103610

14. Leyla Zhuhadar, Rong Yang, Miltiadis D. Lytras, The impact of Social Multimedia Systems on cyberlearners, Computers in Human Behavior (2013/3/1).

15. E.Ya. Egorchenkova, A.G. Zavyalova, A.V. Kravchenko, Foreign languages at school 3, 20-24 (2003); 29 (2) 378-385 (2013). https://doi.org/10.1016/j.chb.2012.09.009

16. Mihaela Cozma, Procedia - Social and Behavioral Sciences 197, 1209-1214 (2015). https://doi.org/10.1016/j.sbspro.2015.07.380

17. V.V. Abraukhova, T.I. Vlasova, N.A. Mamchits, E.I. Egorova, Content of multimedia orientations of students: risks and ways of their pedagogical overcoming within the framework of social partnership/Electron, SHS Web of Conferences, (Trends in the Development of Psycho-Pedagogical Education in the Conditions of Transitional Society (ICTDPP-2019), Rostov-on-Don, Russia, November 22-23, 2019) 70, 6 (2019).

URL:https://www.shsconferences.org/articles/shsconf/pdf/2019/11/shsconf_ictdpp201 8_03006.pdf

18. V.V. Abraukhova, Tahir Tavukchu, A.M. Kalimullin, A.V. Litvinov, N.N. Shindryaeva, N.M. Abdikeev, Electr. International Journal of New Technologies in Training (iJET) 15 (23), 108-120 (2020). https://online-journals.org/index.php/ijet/issue/view/581 